\title{
PENGARUH MASA PAKAI DAN TINGKAT TRANSMISI TERHADAP KADAR EMISI GAS BUANG SEPEDA MOTOR HONDA ASTREA GRAND
}

\author{
I Made Adi Sayoga* \\ * Dosen Jurusan Teknik Mesin Universitas Mataram NTB, JI. Majapahit No 62 Mataram
}

\begin{abstract}
Recently reducing emissions of the harmful gases that generated in the combustion process of the automobile and other internal combustion engine is absolutely essential to environmental preservation. These emissions pollute the environment and contribute to the global warming, acid rain, smog, odours, and respiratory and other health problems. Therefore many countries around the world are taking major efforts to toughen emission standards. Motor cycles, the lagers amount, contributed the major air pollution in Indonesia. The hamful gases that generated in the motor cycles especially $\mathrm{CO}, \mathrm{HC}$ and NOx. As the motor cycles is getting older, many components in the combustion system are getting worst and contribute more hamfull emissions.

This research was done on July 2001 to find out the emissions and was done on Honda Astrea Grand which have been used since 1995, 1996 dan 1997 on the variety of gear level. A multigas analyser was used to analyse the emission gas out form the tile pipe.

The result shows that the maximum $\mathrm{CO}$ and $\mathrm{HC}$ emission are generated by all motor cycle on the first gear. The higerst CO and HC emission is generated by the olderst motor cycle (1995) and the minimum CO and $\mathrm{HC}$ emission is generated by the motor cycle that has been used since 1997.
\end{abstract}

Key words: emission, combustion, gear level

\section{Pendahuluan}

Kendaraan bermotor pribadi yang banyak dimiliki oleh masyarakat adalah sepeda motor. Jumlah kendaraan sepeda motor dari tahun ke tahun senantiasa menunjukkan peningkatan yang sangat signifikan. Bertambahbanyaknya jumlah sepeda motor ini akan berdampak pada segala aspek kehidupanmasyarakat. Di satu pihak menunjukkan peningkatan kualitas kehidupan masyarakat di pihak lain akan memperparah terjadinya pencemaraan udara.

Dampak ganda (multiplier effect) yang positif juga akan terjadi karena terbukanya usaha dalam bidang otomotif, terciptanya lapangan kerja yang luas dari bahan, produksi sampai pemasaran kendaraan bekas, penguasaan teknologi dan sebagainya (Dasuki, 1994). Namun di lain pihak akan mengkibatkan efek buruk seperti peningkatan polusi udara, permasalahan lalu lintas di jalan raya, sampai pada kebisingan.

Bila kendaraan bermotor yang masa pakainya (umurnya) terlalu lama masih dipergunakan di jalan raya, maka akan membahayakan pengendara dan menyebabkan polusi udara yang makin parah. Material yang dipergunakan sebagai bahan konstruksi pada sebuah sepeda motor telah dirancang memiliki umur tertentu agar dapat bekerja sesuai dengan spesifikasinya. Ditinjau dari emisi gas buang yang dikeluarkan dari proses pembakaran dalam silinder maka komponen pendukung terjadinya pembakaran merupakan factor yang sangat penting dalam mengendalikan gas buang yang berbahaya. Jika komponen tersebut mengalami perubahan maka gas buang yang berbahaya akan terbentuk semakin banyak.

Peningkatsn jumlah polutan yang berbahaya bagi lingkungan juga diperparah dengan rendahnya tingkat pemahaman masyarakat tentang bahaya gas buang kendaraan bermotor dan juga peraturan pembatasan kadar emisi gas buang yang berlaku di Indonesia belum begitu ketat. Bila kondisi seperti ini terus dibiarkan berlangsung tanpa dipikirkan cara penanggulangannya maka akan terjadi bahaya yang sangat serius terhadap kelestarian lingkungan. Oleh karena itu perlu dilakuak suatu penelitian tentang pengaruh masa pakai kendaraann bermotor terhadap emisi gas baung yang dikeluarkan dari knalpot.

Perubahan yang terjadi pada komponen pendukung proses terjadinya pembakaran pada sepeda motor, baik itu keausan, perubahan dimensi akibat temperatur maupun proses korosi akan meningkat sejalan dengan lamanya kendaraan tersebut dipergunakan sehingga proses 
pembakaran yang terjadi semakin tidak sempurna. Pembakaran yang semakin tidak sempurna akan memperbanyak terbentuknya emisi gas buang yang berbahaya. Oleh karena itu permasalahan yang ingin diteliti adalah pengaruh masa pakai kendaraan terhadap kadar emisi gas buang yang dikeluarkan pada sepeda motor Honda Astrea Grand.

\section{Landasan Teori}

Pada saat ini motor yang dipergunakan adalah berbagai jenis ada motor listrik, motor bakar dan lain sebagainya. Menurut penyalaan bahan bakarnya motor dapat dibedakan menjadi 2 macam yaitu motor penyalaan bunga api listrik (spark Ignition ) dan motor bakar penyalaan kompresi (Compression Ignition). Motor penyalaan bunga api listrik menggunakan alat untuk menimbulkan bunga api listrik sedang motor penyalaan kompresi menggunakan tekanan dan temperatur yang tinggi untuk pembakaran bahan bakar.

Oleh sebab itu motor penyalaan bunga api listrik menggunakan bensin sebagai bahan bakar, sehingga umumnya disebut Motor Bensin. Sedang bahan bakar yang digunakan untuk penyalaan kompresi adalah solar, yang sering disebut Motor Diesel sesuai dengan nama penemunya Rudolf Diesel.

Motor bensin dibedakan menjadi 2 jenis yaitu Motor Bensin dua langkah (Two Stroke Gasoline Engine). Motor Bensin 4 langkah ( Four Stroke Gasoline Engine ). Motor Bensin dua langkah adalah motor yang menyelesaikan siklus dalam dua kali langkah torak dan sekali putaran poros engkol dengan satu kali usaha ataukerja. Sedangkan Motor Bensin 4 langkah adalah motor yang menyelesaikan siklus dalam empat langkah torak dan satu kali proses pembakaran dan menghasilkan satu kali usaha atau kerja.

Umur sepeda motor adalah berkaitan dengan jumlah periode waktu yang bias dicapai oleh sepeda motor untuk dapat beroperasi . Salah satu factor yang penting dan berpengaruh terhadap umur adalah tingkat keausan kerusakan.

Pada tahun kelima waktu pemakaian merupakan masa yang kritis bagi komponenkomponen mesin pada sebuah produk sepeda motor. Karena pada tahun kelima ini terjadi banyak kerusakan komponen mesin pada sepeda motor. Beberapa kerusakan yang terjadi akibat factor waktu antara lain : kerusakan dinding silinder (ruang bakar), keausan torak dan cincin torak,
Tujuan dari penelitian in adalah untuk menentukan pengaruh masa pakai kendaraan terhadap kadar emisi gas buang yang dihasilkan terutama kadar $\mathrm{CO}$ dan HC. Di samping itu juga menentukan kondisi layak pakai sepeda motor sehingga dapat diperkirakan waktu yang tepat untuk melakukan rekondisi atau reparasi terhadap kendaraan tersebut.

kerusakan karburator, kerusakan pada saringan bahan bakar, kerusakan saringan udara

Pembakaran adalah kombinasi secara kimiawi yang berlangsung cepat antara oksigen dengan unsure yang mudah terbakar dari bahan bakar pada suhu dantekanan tertentu. Di dalam bahan bakar secara umum hanya terdapat tiga unsure yang penting yaitu: karbon, hydrogen dan belerang. Belerang biasanya hanya merupakan unsur ikutan dengan panas pembakaran yang tidak besar tetapi mempunyai peranan yang penting dalam masalah korosi dan pencemaran. ( Tjokrowisastro, et..al, 1987).

Sedangkan udara pada umumnya diasumsikan terdiri dari dua komponen utama yaitu oksigen dan nitrogen dengan komposisi sebagai berikut .

Tabel 1 Komposisi Oksigen dan Nitrogen

\begin{tabular}{|l|l|l|}
\hline Unsur & $\begin{array}{l}\text { Prosentase } \\
\text { Volume }\end{array}$ & $\begin{array}{l}\text { Prosentase } \\
\text { Berat }\end{array}$ \\
\hline Oksigen & 20,99 & 23,15 \\
\hline $\begin{array}{l}\text { Nitogen } \\
\left(\mathrm{N}_{2}\right)\end{array}$ & 78,03 & 76,85 \\
\hline Lain-lain & 0,98 & - \\
\hline \multicolumn{2}{|c|}{ Di dalam pemakaian pembakaran yangs }
\end{tabular}

sebenarnya tidak semua unsure dalam bahan bakar terbakar dengan sempurna. Sebagai contoh pembakaran karbon (C) tidak seluruhnya menjadi $\mathrm{CO}_{2}$ seperti reaksi berikut ini :

$\mathrm{C}+\mathrm{O}_{2} \longrightarrow \mathrm{CO}_{2}$

Tetapi terbakar menjadi $\mathrm{CO}$ atau dalam bentuk aslinya,

$\mathrm{C}+1 / 2 \mathrm{O}_{2}$
$\mathrm{CO}+1 / 2 \mathrm{O}_{2}$
Seperti $\underset{\text { telah }}{\mathrm{CO}} \mathrm{CO}_{2}$ diuraikan sebelumnya, adapun penyebab utama terjadinya pembakaran tidak sempurna adalah : Perbandingan campuran udara dan bahan bakar yng tidak sempurna dimana rasio teoritis adalah 14,7:1, Quenching effect, yaitu campuran gas dekat dinding ruang bakar yang dingin tidak ikut terbakar dan tersapu keluar pada langkah buang,

Di dalam pembakaran energi kimia diubah menjadi energi panas. Pada setiap pembakaran 
selalu dihasilkan gas sisa hasil pembakaran yang disebut gas buang. Adapun komponen-komponen gas tersebut antara lain : $\mathrm{CO}_{2}, \mathrm{H}_{2} \mathrm{O}, \mathrm{NO}_{2}, \mathrm{SO}_{2}$ dan CO.

Apabila pembakaran yang terjadi ruang bakar secara sempurna maka tidak akan dihasilkan gas karbon monoksida. Sesuai dengan persaman berikut :

$\mathrm{Cn}_{2 n+2}+\mathrm{O}_{2} \longrightarrow \mathrm{CO}_{2}+\mathrm{H}_{2} \mathrm{O}$

Pencemaran oleh Gas Buang

Pencemaran yang diakibatkan oleh gas buang dari kendaraan bermotor akhir-akhir ini sangat menarik perhatian karena dapat mengotori udara terutama sekali daerah-daerah padat lalu lintas seperti kota-kota besar ataupun kawasan yang dekat dengan kegiatan industri/pabrik.

Sepeda motor merupakan penyumbang polusi udara terbesar di Indonesia. Polusi udara yang disebabkan oleh sepeda motor berasal dari penguapan tangki bahan bakar, penguapan dari karburator, Blow by crankcase, dan gas buang (Dasuki;1994).

Persentase polusi pada sepeda motor berdasarkan penyebabnya adalah gas buang kendaraan bermotor $(65 \%$ - 85\%), Blow by Crankcase (20\%), Penguapan bahan bakar tangki $(5 \%)$, Penguapan bahan bakar pada karburator (5\% - 10\%) (Obert;1973)

Adapun polutan-polutan dari gas buang yang sangat mengganggu kesehatan seperti :

a. Karbon Monoksida (CO)

Karbon Monoksida (CO) merupakan gas yang cukup banyak terdapat diudara yang terjadi dari sumber-sumber yang mengalami pembakaran yang tidak sempurna. Gas ini bersifat tidak berbau, tak dapat dirasakan dan tak berwarna. Pada saat bernafas gas ini ikut terhisap dan ketika sampai di paru-paru bergabung atau terikat dalam hemoglobin $(\mathrm{Hb})$ dan membentuk senyawa Karboksi Hemoglobin $(\mathrm{COHb})$. Dengan terikatnya gas $\mathrm{CO}$ ini dalam hemoglobin, menyebabkan berkurangnya kemampuan hemoglobin untuk mengikat oksigen. Kekurangan oksigen dalam darah menyebabkan proses pembakaran dalam sel menjadi berkurang. Affinitas untuk mengikat hemoglobin bagi gas karbon monoksida adalah 210 kali dari oksigen, sehingga dapat dibayangkan bila didalam udara pernafasan yang kita hirup mengandung gas karbon monoksida akan dengan sendirinya sangat mengganggu pengangkutan oksigen oleh hemoglobin.

Gas CO itu baru dpat diserap oleh mikroorganisme da stratosfer dalam waktu enam bulan sehingga cukup lama mencemari lingkungan. Daya ikat hemoglobin terhadap CO 210 kali lebih kuat daripada $\mathrm{O} 2$ sehingga dapat dipahami bahwa seseorang yang menghirup udara dengan kadar CO $1 \%$ selama satu jam akan kehilangan $60 \%$ O2 dan hal ini pasti mengganggu fungsi kontrolotak manusia sehingga kematian kita dating tanpa kita sadar dan mungkin tanpa rasa sakit.

b. Sulfur dioksida (SO2)

Sulfur dioksida didapat baik dari sumber alamiah maupun sumber artificial. Sumber-sumber alamiah SO2 adalah gunung-gunung berapi, pembusukan bahan organic oleh mikroba, dan reduksi sulfat secara biologis. Sumber-sumber SO2 buatan adalah pembakaran bahan bakar minyak,gas, dan batu bara yang mengandung sulfur tinggi (Selamet, et.al, 1994). SO2 dikenal sebagai gas yang tidak berwarna bersifat iritan kuat bagi kulit dan selaput lendir, pada konsentrasi $6-12 \mathrm{ppm}$. SO2 mudah diserap oleh selaput lendir saluran pernafasan bagian atas. Dalam kadar rendah dapat menimbulkan spasme temporer otot-otot polos pada bronchioli. Spasme ini dapat menjadi lebih hebat pada selapu lendir disaluran pernafasan pada bagian atas, dan apabila kadar SO2 dapat bertambah tinggi lagi maka akan terjadi peradangan yang hebat pada selaput lendir, bila kadar ini rendah $(6-12 \mathrm{ppm})$ tetapi bila pernafasan terjadi berulang kali, maka akan menyebabkan kanker disamping itu juga sulfur dioksida juga merupakan salah satu komponen penyebab terjadinya hujan asam. Hujan asam ini akan mempercepat berkaratnya alat/bahan yang terbuat dari logam sehingga menyebabkan kerusakan yang lebih cepat.

c. Hidrokarbon ( $\mathrm{HC}$ )

Hidrokarbon dapat berasal dari proses alamiah dan buatan manusia. Secara alamiah hidrokarbon diproduksi oleh tanaman, dekomposisi zat organic. Sumber alamiah bagi hidrokarbon adalah sumursumur minyak dan gas bumi. Sumber utama hidrokarbon adalah asap gas bermotor. Kebanyakan hidrokarbon yang didapat adalah metana. Sekalipun hidrokarbon tersebut merupakan gas yang beracub bagi manusia, dalam udara bebas tidak menimbulkan masalah serius, kecuali bagi mereka yang terpapar oleh jelaga yang mengandung $\mathrm{HC}$ yang bersifat karsinigenik, maka akan menyebabkan kanker (Slamet,et.al,1994).

d. Nitrogen Oksida $\left(\mathrm{NO}_{2}\right)$

Gas ini menyebabkan bengek/sesak nafas pada penderita asma dan juga mengakibatkan kabut/asap. NOx adalah gas yang tidak berwarna dan dapat segera menjadi gas $\mathrm{NO}_{2}$ karena bersenyawa dengan $\mathrm{O}_{2}$, NOx terbentuk karena 
temperatur tinngi dari suatu pembakaran ( Slamet,

\section{Metodologi Penelitian}

Alat dan Bahan penelitian

Peralatan yang dipergunakan dalam penelitian ini adalah

1. Alat peguji kadar gas buang multi gas analyser type CZ Sincro EGA 320.

2. Tachometer untuk mengukur putaran mesin

3. Peralatan pendukung lainnya.

4. Sepeda motor Honda Astrea Grand.

Sepeda motor yang dipergunakan dalam penelitian ini diambil secara acak dengan mempertimbangkan tahun keluaran yaitu keluaran tahun 1995, 1996 dn 1997. dengan angka jarak tempuh pada speedometer berturut-turut 17.400 $\mathrm{km}, 14.900 \mathrm{~km}$ dan $12.000 \mathrm{~km}$.

Pengujian kadar gas buang $\mathrm{CO}$ dan $\mathrm{HC}$ dilakukan pada berbagai tingkat transmisi yitu netral, transmisi 1, transmisi 2, transmisi 3, transmisi 4. pada putaran $1500 \mathrm{rpm}$ dan dilakukan pengulangan sebanyak 3 kali.

Data yang didapat diolah dengan analisis of varian.

\section{Pembahasan.}

\section{Emisi CO}

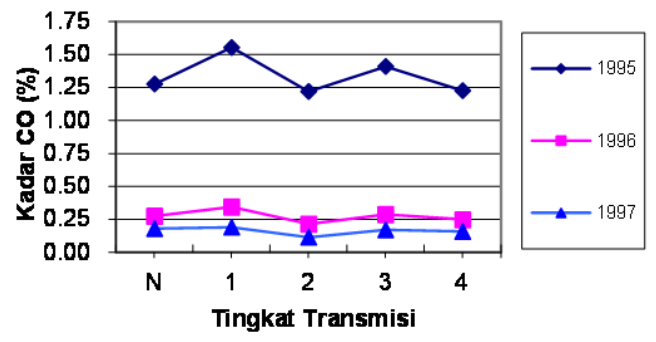

Grafik 1. Hubungan tingkat transmisi terhadap kadar CO dari tahun keluaran sepeda motor

Pada sepeda motor Honda Astrea Grand Tahun 1995 (masa pakai 6 tahun) kadar CO maksimum terjadi pada tingkat trasmisi 1 , yaitu sebesar 1,56 \%. Pada sepeda Motor Honda Astrea Grand 1997 (masa pakai 4 tahun) kadar CO maksimum terjadi pada tingkat trasmisi 1 , yaitu sebesar $0,19 \%$. Jadi pada dasarnya kadar CO maksimum dari setiap variasi tahun (masa pakai) sepeda motor terjadi pada tingkat trasmisi et.al,

1. Apabila kadar CO kita tinjau untuk semua maka kadar CO maksimum yang dihasilkan terjadi pada untuk sepeda motor tahun 1995 ( umur 6 tahun) yaitu sebesar $1,56 \%$. Kadar CO minimum terjadi pada sepeda motor dengan masa pakai sepeda motor 4 tahun (tahun 1997).

Hal ini dapat dijelaskan sebagai berikut: seperti kita ketahui bahwa gas CO akan terbentuk apabila keadaan campuran bahan bakar - udara "kaya" (AFR teoritis tidak terpenuhi). Dalam proses pembakaran yang berlansung didalam ruang bakar (silinder) akan terjadi kekurangan oksigen. Pada kondisi idle (tingkat transmisi Netral) campuran bahan bakar - udara menjadi kaya (komposisi bensin lebih banyak ), hal ini dikuatkan dengan terbentuknya gas buang $\mathrm{CO}$ maksimum yang dihasilkan pada kondisi pembebanan ini. Karena pada saat pembebanan 1 (tingkat transmisi 1) dibutuhkan daya yang besar. Inilah menyebabkan pembakaran bahan bakar menjadi tidak sempurna akibat bahan bakar yang kekurangan oksigen, sehingga tidak semua bahan bakar yang masuk kedalam silinder terbakar semuanya, sehingga dapat dipastikan prosentase gas $\mathrm{CO}$ yang dihasilkan cukup tinggi pada gas buang sepeda motor. Seiring dengan pembebanan selanjutnya (gigi 2), keadaan campuran bahan bakar - udara mendekati campuran bahan bakar - udara untuk proses pembakaran sempurna yaitu sebesar 1 : 14,8 dalam satuan berat, dimana campuran bahan bakar menjadi lebih miskin daripada keadaan pada saat tingkat transmisi 1. Ini dikuatkan dengan menurunnya gas $\mathrm{CO}$ yang terbentuk dalam gas buang. Pada saat diberi pembebanan selanjutnya yaitu transmisi 3 gas $\mathrm{CO}$ yang dihasilkan pada gas buang kembali mengalami peningkatan ( $\mathrm{CO}$ yang dihasilkan lebih tinggi bila dibandingkan dengan $\mathrm{CO}$ pada transmisi 2). Pada saat diberikan pembebanan selanjutnya yaitu transmisi4 $\mathrm{CO}$ yang dihasilkan kembali mengalami penurunan, tetapi nilainya masih lebih besar bila dibandingkan dengan kadar $\mathrm{CO}$ yang dihasilkan pada tingkat transmisi 2 (menurut teori semakin tinggi tingkat transmisi, maka kadar $\mathrm{CO}$ yang dihasilkan juga semakin sedikit). Hal ini akibat dari perlakuan putaran yang konstan ( $1500 \mathrm{rpm}$ ).

Tidak terpenuhinya AFR teoritis dan adanya sebagian bahan bakar yang tidak terbakar ( Quenching effect) yang ikut keluar bersama gas buang disebabkan oleh umur material (bahanbahan) komponen-komponen mesin sepeda motor terutama komponen yang berperan dalam proses pembakaran yang mengalami kerusakan. Hal ini dapat dilihat dengan semakin tua umur (masa 
pakai) kendaraan maka semakin banyak gas CO yang dihasilkan, karena semakin tua umur sepeda motor maka komponen- komponen mesin (yang berperan penting pada prosespembakaran) telah banyak mengalami keausan. Dimana pada tahun kelima merupakan tahun kritis bagi komponenkomponen mesin dari sebuah sepeda motor, sehingga pada tahun kelima umumnya semua komponen tersebut harus dirombak karena operasinya tidak optimal lagi. Disamping itu juga, banyaknya kotoran-kotoran yang menempel pada saringan udara sehingga udara tidak lancar masuk ke karburator yang berakibat campuran menjadi kaya.

\section{Penyebab-penyebab}

terjadinya pembakaran yang tidak sempurna yang terjadi di dalam ruang bakar sehingga menghasilkan gas CO antara lain: saringan udara kotor/rusak, setelan karburator kurang baik, pipa pancar utama (main nozzle) sudah aus, main jet kendor (lubangnya terlalu besar), cincin torak dn dinding ruang bakar telah aus, cincin kompresi torak aus.

Table analisis varian dari emisi gas $\mathrm{CO}$ adalah seperti berikut.

\begin{tabular}{|l|l|l|l|l|c|}
\hline \multicolumn{1}{|c|}{ S V } & DK & JKt & RK & Fhit & $\begin{array}{c}\mathrm{Ft} \\
1 \%\end{array}$ \\
\hline $\begin{array}{l}\text { Perl. } \\
\text { Transmisi }\end{array}$ & 4 & 0.18 & 0.045 & $45^{\star *}$ & 4.02 \\
\hline $\begin{array}{l}\text { Perl. } \\
\text { Tahun }\end{array}$ & 2 & 12.64 & 6.32 & $6320^{\star *}$ & 5.39 \\
\hline Interaksi & 8 & 0.1 & $\begin{array}{l}0.012 \\
5\end{array}$ & $12.5^{\star *}$ & 3.17 \\
\hline Error & 30 & 0.03 & 0.001 & & \\
\hline Jumlah & 44 & 28.65 & & & \\
\hline
\end{tabular}

Keterangan $^{* *}$ menunjukan pengaruh yang sangat nyata

Dari analisis of varian diketahui bahwa perlakuan transmisi, tahun sepeda motor serta interaksi antara keduanya menunjukkan pengaruh yang sangat signifikan terhadap kadar gas $\mathrm{CO}$ yang dihasilkan (taraf signifikansi 1\%)

\section{Emisi HC}

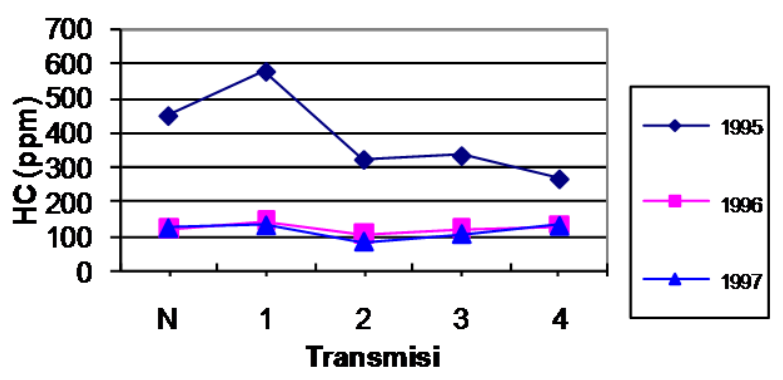

Grafik 2. Hubungan tingkat transmisi terhadap kadar HC dari tahun keluaran sepeda motor
Pada sepeda motor Honda Astrea Grand tahun 1995 dengan masa pakai 6 tahun kadar emisi HC maksimum terjadi pada transmmisi 1 , yaitu sebesar 579 ppm, sedangkan pada sepeda motor keluaran ahun 1996 dengan masa pakai 5 tahun kadar emisi HC maksimum juga terbentuk pada transmisi 1 yaitu sebesar $146 \mathrm{ppm}$ dan sebesar $132 \mathrm{ppm}$ pada sepeda motor keluaran tahun 1997 dengan masa pakai 4 tahun. Jadi terlihat jelas bahwa kadar emisi HC terbentuk pada transmisi 1 pada semua sepeda motor, namun kadar emisi $\mathrm{HC}$ akan turun seiring dengan makin pendeknya masa pakai sepeda motor tersebut.

Emisi gas buang $\mathrm{HC}$ adalah gas yang dihasilkan karena adanya campuran bahan bakar yang tidak ikut/sempat terbakar didalam ruang bakar dan terdesak kelaur ruang bakar pada saat langkah buang. Terjadinya pembakaran yang tidak sempurna di dalam ruang bakar dapat diakibatkan oleh beberapa factor seperti besarnya crivece volume, rendahnya kompresi pada saat langkah compresi, tingginya kebocoran akibat tingginya keausan komponen silinder, dan quenching effect yang besar. Pembakaran yang kurang sempurna akan membentuk lapisan kerak di sekitar ruang bakar sehingga banyak campuran bahan bakar yang terperangkap di antara kerak tersebut dan pada saat pembakaran tidak akan terbakar dengan sempurna hal ini ikut memperbesar emisi gas buang $\mathrm{HC}$ yang terbentuk.

Makin lama masa pakai sebuah sepeda motor maka tingkat keausan komponen akan semakin tinggi pula. Kerak atau enddapan arang yang menumpuk di ruagn bakar akan semakin tebal sehingga quenching effect akan semakin tinggi maka kemungkinan terjadinya pembakaran yang kelurang sempurna akan semakin besar oleh karena itu makin tinggi pula emisi $\mathrm{HC}$ yang timbul.

Disamping hal tersebut di atas, perbandingan campuran bahan bakar dengan udara (AFR) juga factor yang sangat penting dalam terbentuknya gas HC. Pembakaran yang sempurna antara bahan bakar bensin dengan udara di dalam silinder memerlukan perbandingan yang tertentu yang disebut dengan kondisi stoichiometric dimana $1 \mathrm{~kg}$ bahan bakar bensin memerlukan ekitar 14,7 kg bahan bakar. Jika AFR ratio tidak tercapai maka akan terjadi pembakaran yang tidak sempurna. Pembakaran campuran bahan bakar udara yang kaya (rich) akan memperbesar timbulnya emisi HC, oleh karena banyaknya bahan bakar yang tidak sempat/ikut terbakar (karena kekurangan oksigen).

Selain hal tersebut beberapa factor yang ikut menjadi penyebab timbuknya emisi $\mathrm{HC}$ adalah 
seperti saringan udara yang kotor/rusak, stting carburator yang salah/kurang baik, main nozzle yang aus, main jet yang aus, banyaknya endapan kerak di dalam ruang bakr, serta ausnya cincin dan dinding torak.

Table analisis varian dari emisi gas $\mathrm{HC}$ adalah seperti berikut.

\begin{tabular}{|l|l|l|l|l|r|}
\hline \multicolumn{1}{|c|}{ S V } & DK & JKt & RK & Fhit & $\begin{array}{r}\text { Ft } \\
1 \%\end{array}$ \\
\hline $\begin{array}{l}\text { Perl. } \\
\text { Transmisi }\end{array}$ & 4 & 70456 & 17614 & $49.48^{\star *}$ & 4.02 \\
\hline Perl. & 2 & 854086 & 427043 & $1200^{\star *}$ & 5.39 \\
\hline
\end{tabular}

\section{Kesimpulan}

Berdasarkan analisa dapat ditarik kesimpulan sebagai berikut:

1. Sepeda Motor Honda Astrea Grand tahun 1997 (masa pakai 4 tahun) mengeluarkan emisi $\mathrm{CO}$ yang lebih kecil dibandingkan dengan sepeda motor dengan masa pakai yang lebih panjang yaitu Sepeda Motor Honda Astrea Grand tahun 1996, dan sepeda Motor Honda Astrea Grand tahun 1995. Emisi CO maksimum terjadi pada sepeda motor dengan masa pakai 6 tahun dan terendah pada sepeda motor dengan masa pakai 4 tahun

2. Emisi gas HC yang dikeluarkan Sepeda Motor Honda Astrea Grand tahun 1997 lebih rendah dibandingkan dengan Sepeda Motor Honda Astrea Grand tahun 1996 dan Sepeda Motor Honda Astrea Grand tahun 1995. Emisi HC maksimum terjadi pada sepeda motor dengan masa pakai 6 tahun dan terendah pada sepeda motor dengan masa pakai 4 tahun

3. Emisi $\mathrm{CO}$ dan $\mathrm{HC}$ maksimum pada semua tahun sepeda motor dikeluarkan pada transmisi 1

\section{Daftar Pustaka}

1. Dasuki, F.S., 1994. Kontrol Emisi Gas Buang pada Sepeda Motor. PT. Federal Motor, Jakarta

2. Kiyaku, Y., Murdhana, D.M., 1998. Teknik Praktis Merawat Sepeda Motor. Cetakan Kedua, Pustaka Setia, Bandung.

3. Marshall, E.L., Owen, K., 1995. Motor Gasoline, The Royal Society of Chenistry, England.

4. Nevers, N.D., 2000. Air Pollution Control Engineering. Second edition, McGraw Hill International, Singapore.

\begin{tabular}{|l|l|l|l|l|l|}
\hline Tahun & & & & & \\
\hline Interaksi & 8 & 71717 & 8965 & $25^{\star *}$ & 3.17 \\
\hline Error & 30 & 10667 & 356 & & \\
\hline Jumlah & 44 & 28.65 & & & \\
\hline
\end{tabular}

Keterangan ** menunjukan pengaruh yang sangat nyata

Dari analisis of varian diketahui bahwa perlakuan transmisi, tahun sepeda motor serta interaksi antara keduanya menunjukkan pengaruh yang sangat signifikan terhadap kadar gas $\mathrm{HC}$ yang dihasilkan (taraf signifikansi 1\%)

5. Obert, E.F., 1973. International Combustion Engines and Air Pollution. Harper and Row Publishers. New york.

6. Saleh, S. 1997. Satistik Induktif. Cetakan Kedua, UPP AMP YKPN, Yogyakarta.

7. Slamet, Juli, S. 1994. Kesehatan Lingkungan. Gajah Mada University Press, Yogyakarta.

8. Taylor, C.F. 1987. The Internal Combustion Engine in Theory and Practise, Revised Edition, The MIT Press, England. 